\title{
Determining the Attitudes and Metaphoric Perception of Prospective Science Teachers toward Biology Courses
}

\author{
Sule Firat Durdukoca ${ }^{1}$ \\ Arzu Önel ${ }^{2}$ (iD
}

'Kafkas Univercity, Education Faculty, Special Education Department, Kars, Turkey. Email:drsulefirat@gmail.com Tel: +90 5530086244

'Kafkas Univercity, Education Faculty, Mathematic and science Education Department, Kars, Turkey.

Email:arzuonel@gmail.com Tel: +90 5554191660

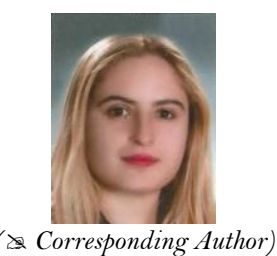

\section{Abstract}

This study aimed to determine the attitudes and metaphorical perceptions of science teacher candidates towards biology lesson. In the study, a mixed method and triangulation pattern was used. A survey form developed by the researchers to determine the metaphorical perceptions of the teacher candidates about biology lesson and their demographic information and a "Biology Course Attitude Scale (BDTÖ)" were used to determine their attitudes towards the biology lesson. SPSS package program was used for analysis of quantitative data and content analysis technique was used for analysis of qualitative data. Metaphores developed by science teacher candidates are alphabetically ordered; coded, categorized, percent and frequency values are calculated. Participant teacher candidates' attitudes towards the biology lesson in general were found to be positive at the "I agree" level. As a result of the research, it was determined that the teacher candidates' attitude scores related to the biology lesson did not show any significant difference according to gender and grade levels. It was determined that science teachers candidates participating in the research had 117 valid metaphors and 57 different metaphors for the biology lesson, and the metaphors of "life" ( $f=37$ ) and "water" ( $f=6)$ were the most frequently produced metaphors.

Keywords: Biology course, Science teacher candidates, Metaphor, Attitude, Mixed method, Triangulation pattern.

Citation | Sule Fırat Durdukoca; Arzu Önel (2020). Determining the Attitudes and Metaphoric Perception of Prospective Science Teachers toward Biology Courses. Asian Journal of Education and Training, 6(2): 136-143.

History:

Received: 4 December 2019

Revised: 9 January 2020

Accepted: 13 February 9090

Published: 19 Mard 2020

Published: 19 March 2020
Licensed: This work is

Licensed: This work is licensed under a Creative Commons

Attribution 3.0 License $(\mathrm{oc})$

Publisher: Asian Online Journal Publishing Group
Acknowledgement: Both authors contributed to the conception and design of the study.

Funding: This study received no specific financial support.

Competing Interests: The authors declare that they have no conflict of interests.

Transparency: The authors confirm that the manuscript is an honest, accurate, and transparent account of the study was reported; that no vital features of the study have been omitted; and that any discrepancies from the features of the study have been omitted;
study as planned have been explained.

Ethical: This study follows all ethical practices during writing.

\section{Contents}

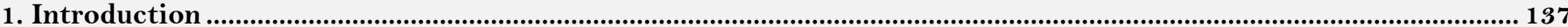

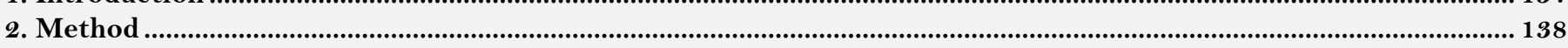

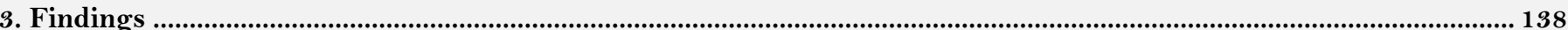

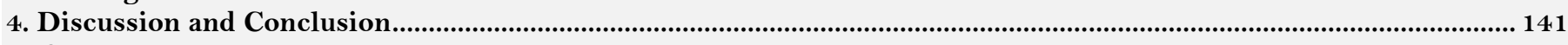

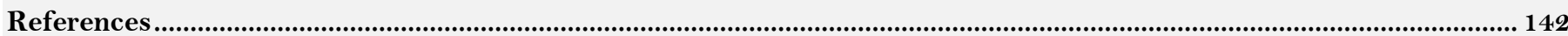




\section{Contribution of this paper to the literature}

This research is the only study that examined teacher candidates' attitudes and perceptions towards biology course in mixed methods and in the same research.

\section{Introduction}

Biology analyzes the molecules and cells forming the living things on a microscopic scale and the whole world of living creatures on a global scale (Reece et al., 2013). The world of living things comprises a broad range of ecosystems varying from $10 \mathrm{~km}$ depths of the oceans to $65 \mathrm{~km}$ altitudes of the atmosphere (Lodish et al., 2011). From this aspect, biology can be regarded as a branch of science involving social, environmental and health issues like the composition of the soil, agriculture, animal husbandry, nutrition, diseases, marriage, family relations, learning, memory, and environment, suggesting solutions to many problems related to these issues, presenting the latest developments in human life day by day, and proliferating.

The shortage of knowledge about biology often caused problems and has continued to create them. Namely, people with little or no knowledge have resorted to violence and even murdered women in many parts of the world because they did not give birth to boys for long years (Simşek, 2011; Unal, 2005). Still, a person knowing the fundamental matters about fertilization, one of the biological matters, comprehends that the element determining the male gender is the "Y" chromosome and is transferred from father to son so that the mother has no involvement in this issue.

Biology is significant in resolving numerous environmental problems. As a result of people's inappropriate behaviors, biodiversity is shrinking, global climate change is undergone, and the incidents like glacier melting and droughts are increasing rapidly (Tosun, 2011). The reason behind them is the shortage of knowledge about biology or negative attitudes toward environmental issues (Atasoy \& Ertürk, 2008) because environmental education and awareness can be obtained through biology courses (Atasoy \& Ertürk, 2008; Unal. \& Dımışkı, 1999).

Biology is essential to solving problems associated with human health (Tosun, 2011). Biological significance of foods, sufficient and well-balanced nutrition, health problems in case of malnutrition can be obtained to individuals within the scope of biology courses. The level of social awareness about drugs and particularly antibiotics also necessitates biology knowledge.

Biology knowledge can only be obtained with biology courses and decisive attitudes and positive insights. Rodrigues, Santos, Teixeira, Gonela, and Zanetti (2012) described the attitude as "an essential structure for comprehending a person's tendency to adopt and sustain specific standards of behavior.” It contains sentiment and prepares for behavior. Therefore, the individual initially obtains knowledge of the object, then displays his or her situation as an affective response and eventually converts it into behavior. Hence, attitude exists at the source of all human behavior. Attitudes toward biology consist of students' feelings like interest, like and dislike, and the scale of attitude measures this (Cömert, 2014). Students are usually unresponsive to the biology course and have adverse attitudes because they often regard it as trivial (Oztürk-Akar, 2014). In such an area of concern in life, giving decisive attitudes to students should be one of the principal objectives of the curriculum at all levels.

Metaphors can be a tool for ascertaining the perceptions of individuals about a subject. We can define them as a tool to facilitate understanding the lesser-known objects, events, concepts, facts, theories by using the known features of the objects, events, concepts, phenomena, theories. Hence, metaphors present assistance in understanding, describing, and structuring a new phenomenon (Morgan, 1998). Forceville (2002) asserts that a metaphor has three principal components: the subject of the metaphor, its source, and characteristics adding to the subject of metaphor. For instance, in the sentence, "Children are the architects of the future because they will shape our future," the word "children" is the subject of metaphor, the word "architects of the future" the source of metaphor, and the expression, "because they will shape our future" is the characteristic adding to the subject of metaphor (Ummanel, 2017). Metaphors are used for developing the insight and understanding of learners and identifying how they regard an object, event, situation (Zheng \& Song, 2010). Currently, it is intended to ascertain the perceptions of participants through metaphors in various studies.

Perception has central importance for any discipline concerning human behavior and learning. In various studies on observing teachers' views about various subjects, perceptions were determined to guide teachers' instructional behaviors. Still, perception is a theoretical structure exhibited with assistance. One of the factors presenting such assistance to the individual is metaphors (Zheng \& Song, 2010). In the study, it is intended to show prospective teachers' perceptions about the biology course through metaphors. Cognitive, affective, and behavioral characteristics of the course can be settled with metaphors created by prospective biology teachers presenting the essential information about life, and the necessary actions to increase the attitude level, in other words, to provide better biology education, can be revealed.

In the literature, students' attitudes toward biology course are studied at the level of high school (Aktaş, 2012; Atik, Kayabaşı, Yağcı, \& Unlü-Erkoç, 2015; Cömert, 2014; Ekici \& Hevedanlı, 2010; Konu, 2017; Onder, 2015; Ozatlı, 2006; Pehlivan \& Köseoğlu, 2010; Semenderoğlu, 2012; Yapıcı, 2015). Kabaca (2013) analyzed the attitudes of prospective classroom teachers, and Köseoğlu (2010) examined the attitude of prospective biology teachers. There are relatively few studies on this subject (Usak et al., 2009). Besides, various studies analyzing students' metaphoric perceptions about the concept of biology (Gürbüzoğlu-Yalmancı \& Aydın, 2013; Harman \& Cökelez, 2017; Ulukök, Bayram, \& Selvi, 2015; Yapıcı, 2015) are found, while no study on the direct metaphoric perceptions of prospective biology teachers was encountered. Prospective teachers' attitudes toward science are thought to be useful in improving positive/negative metaphors (Harman \& Cökelez, 2017; Osborne, Simon, \& Collins, 2003). Thornbury (1996) asserts that the impact of education on individuals will be partial if no regulation on the awareness level of attitudes is practiced. Hence, ascertaining the attitudes and metaphoric perceptions of prospective teachers toward the biology course is essential to make them aware of their attitudes and perceptions toward the biology course, conveying the data linked to science rapidly developing and presenting the knowledge to humans. 
This study aims to ascertain the attitudes and metaphoric perceptions of prospective teachers toward biology courses. Determining the level of it, how they interpret this course, and display their positive or negative attitudes are central points of research. In this context, the answers to the following questions were inquired:

1. What are the prospective teachers' attitudes toward biology course? Do they vary by the gender and class levels of prospective teachers?

2. What are the metaphors offered by prospective teachers concerning biology course? Under which conceptual categories are they collected?

\section{Method}

\subsection{Research Model}

In the research, a triangulation design, one of the mixed methods, was used. Doğru, Gençosman, Ataalkın, and Seker (2012) stated that the mixed model is the least used research model in biology. Therefore, the research is expected to add to fill an essential gap in the literature.

\subsection{The Study Group of Research}

The study group of the research consisted of prospective teachers training at the department of science education at the faculty of education at Kafkas University in Turkey. Criterion sampling, one of the purposive sampling methods, was practiced. The criterion requires that prospective teachers took the biology course. Therefore, the study was conducted with 136 prospective teachers in the second $(\mathrm{n}=66)$, third $(\mathrm{n}=52)$, and fourth $(\mathrm{n}=18)$ classes of Science Education Department. 65\% $(\mathrm{n}=89)$ were female participants.

\subsection{Data Collection Tools}

The data were obtained by a questionnaire formed by the researchers and the Biology Lesson Attitude Scale (BDTÖ) by Tosun (2011). The part including participants' demographic information and the part in which participants were required to complete the sentence "Biology course is like or similar to ..../ because ...." constitute two parts of the form. The BDTÖ was designed as a 5-point Likert-type and involved 36 items in one dimension. The variance defined by this single factor was assessed as 54.98\%. 7 of 36 items indicated negative attitudes, and 29 of them displayed positive attitudes. The Cronbach-Alpha reliability coefficient of the scale was determined as .96 and in this research, Cronbach-Alpha reliability coefficient of the scale was found to be .89 .

\subsection{Data Analysis}

In the analysis of quantitative data, descriptive analysis, independent groups t-test, and ANOVA test were practiced. The analysis and interpretation of metaphors developed by prospective teachers were conducted by considering the five stages below developed by Saban (2009) following the content analysis technique.

1. Coding: Metaphors created by participants were ordered and coded in alphabetical order.

2. Classification: These metaphors were analyzed in terms of the subject of the metaphor, its source, and the convenience of the characteristics adding to the subject of metaphor. From the content analysis, 117 confirmed, and 57 different metaphors were acquired.

3. Category Development: It was analyzed how 57 different metaphors were conceptualized, and the relevant metaphors were grouped under a single category, and 16 conceptual categories were created.

4. Validity and Reliability: A field expert and an educational science expert were asked to ascertain whether the metaphors describe the associated conceptual category. The reliability of the research was assessed using the formula (reliability= consensus / consensus + dissensus) by Miles and Huberman (1994). Accordingly, the consensus was ensured with experts on 16 conceptual categories, and the reliability level was $91 \%$.

5. Transferring Data to Computer Environment: Metaphors were transferred to the computer environment, and the number (f) and percentage (\%) of each metaphor were estimated.

\section{Findings}

Table 1 shows a descriptive analysis of the biology course attitude scale scores of prospective teachers.

Table-1. The descriptive analysis of the answers to the biology course attitude scale.

\begin{tabular}{l|c|c|c|c}
\hline & Min. & Max. & $\bar{x}$ & ss \\
\hline Biology course attitude scale & 1 & 5 & 3.55 & .96 \\
\hline
\end{tabular}

In Table 1, the attitude scale scores of the participants were observed to be positive at the dimension of "agree." The item mostly agreed by the candidates was "I believe that what I learned in biology course was helpful for me" ( ${ }^{x}{ }_{\text {item10 } 10}=4.28$; $\left.\mathrm{ss}_{\mathrm{item} 10}=.82\right)$, but the item with the lowest participation level by the prospective teachers was "no one has no shortage of biology knowledge" $\left(\bar{x}_{\text {item26 }}=1.55\right.$; $\left.\mathrm{ss}_{\mathrm{item} 26}=.89\right)$. These results reveal that the attitudes of the participants toward the biology course are high.

Table 2 displays the results of data analysis on the prospective teachers' attitudes toward biology courses for the difference by gender.

Table-2. The result of t-test analysis of the participants' biology class attitude scale by gender

\begin{tabular}{|c|c|c|c|c|c|c|c|c|}
\hline \multirow[b]{2}{*}{ Gender } & \multirow[b]{2}{*}{$\mathbf{N}$} & \multirow[b]{2}{*}{$\bar{x}$} & \multirow[b]{2}{*}{$\mathbf{s S}$} & \multirow[b]{2}{*}{$\mathbf{t}$} & \multirow[b]{2}{*}{ df } & \multirow[b]{2}{*}{$\mathbf{p}$} & \multicolumn{2}{|c|}{ Results of Levene-Test } \\
\hline & & & & & & & $\mathbf{F}$ & $\mathrm{p}$ \\
\hline Female & 89 & 125.15 & 14.62 & \multirow[t]{2}{*}{1.53} & \multirow[t]{2}{*}{136} & \multirow[t]{2}{*}{$.12^{*}$} & \multirow[t]{2}{*}{2.66} & \multirow[t]{2}{*}{.10} \\
\hline Male & 49 & 120.85 & 17.72 & & & & & \\
\hline
\end{tabular}


When the average attitude scores of participants were examined in Table 2 by gender, the mean attitude scores of female participants were seen to be higher than that of male participants. Still, no significant difference was determined between the mean scores. It reveals that male and female participants' attitudes are similar to each other.

Table 3 presents the data analysis results of prospective teachers' attitudes the difference by class level.

Table-3. The ANOVA test results of biology courses attitude scale of the participants by class level.

\begin{tabular}{l|c|c|c|c|c}
\hline Class Level & Sum of Square & sd & Mean Square & F & p \\
\hline Inter-group & 1178,50 & 3 & 392.83 & 1.58 & $.19^{*}$ \\
\hline Intra-group & 33204.66 & 134 & 247.79 & & \\
\hline Total & 34383.16 & 137 & & & \\
\hline Note: $\mathrm{p}^{*}<.05$.
\end{tabular}

In Table 3, no significant difference was observed between the prospective teachers' attitude levels by class ( $\mathrm{p}>$ .05). It shows that the attitudes of prospective teachers in the second, third, and fourth classes are close to each other.

In Table 4, metaphors created by prospective teachers concerning biology courses are displayed together with their frequency and percentage values.

\begin{tabular}{|c|c|c|c|c|c|}
\hline Metaphor & $\mathbf{F}$ & $\%$ & Metaphor & $\mathbf{F}$ & $\%$ \\
\hline Weight & 1 & .85 & Torture & 1 & .85 \\
\hline Anatomy & 1 & .85 & Jenga & 1 & .85 \\
\hline Antique Car & 1 & .85 & Heart & 2 & 1.70 \\
\hline Driving a car & 1 & .85 & Cat & 2 & 1.70 \\
\hline Research & 1 & .85 & Exploration & 2 & 1.70 \\
\hline Riddle & 3 & 2.56 & Chemistry & 2 & 1.70 \\
\hline Living things & 3 & 2.56 & Book & 1 & .85 \\
\hline Flower & 3 & 2.56 & Labyrinth & 2 & 1.70 \\
\hline Chocolate & 1 & .85 & Lahmacun & 1 & .85 \\
\hline Drilled plastic bottle & 1 & .85 & Machine & 1 & .85 \\
\hline Trouble & 1 & .85 & Matryoshka & 1 & .85 \\
\hline Nature & 1 & .85 & Miracle & 1 & .85 \\
\hline Doctor & 2 & 1.70 & Oxygen & 1 & .85 \\
\hline Domino & 1 & .85 & Organ & 2 & 1.70 \\
\hline Friend & 1 & .85 & Guide & 1 & .85 \\
\hline Looking to the earth from space & 1 & .85 & Art & 1 & .85 \\
\hline Universe & 1 & .85 & Verbal lesson & 2 & 1.70 \\
\hline Memorizing & 1 & .85 & Water & 6 & 5.13 \\
\hline Fenerbahçe & 1 & .85 & Poetry & 1 & .85 \\
\hline Sapling & 1 & .85 & Prayer bead & 1 & .85 \\
\hline Whirlpool & 1 & .85 & Science & 4 & 3.42 \\
\hline Shadow & 1 & .85 & Horizon line & 1 & .85 \\
\hline Rose & 1 & .85 & Adaptation & 1 & .85 \\
\hline Sun & 1 & .85 & Space & 1 & .85 \\
\hline Dream & 1 & .85 & Life philosophy & 1 & .85 \\
\hline Life & 37 & 31.63 & Life coach & 1 & .85 \\
\hline Life Sciences & 1 & .85 & Puzzle & 3 & 2.56 \\
\hline Drug & 1 & .85 & Food & 1 & .85 \\
\hline First aid kit & 1 & .85 & & & \\
\hline
\end{tabular}

In Table 4, participants were observed to create 117 confirmed metaphors. Metaphors mostly created were "life" (f=37; \%31.63), "water" ( $\mathrm{f}=6$; \%5.13), and "science" ( $\mathrm{f}=4 ; \% 3.42)$. In Table 5, the metaphor groups of conceptual categories are presented.

In Table 5, metaphors are classified under 16 conceptual categories. The number of metaphors for the source of life category is 9. In this category, prospective teachers asserted that biology course is a field comprising almost all kinds of knowledge and skills about life, and this course is essential such as water, sun, heart, and oxygen. One of the participants stated, "Biology course is like life because biology is everywhere and necessary"(S113) while the others said "Biology course is like life because it is a living branch of science" (Student [S] 118), and "Biology is like water because there is no life without water just like in biology (S136)."

The most frequent created metaphors in "a group of topics related to each other" category are "riddle" $(\mathrm{f}=3)$, and "puzzle" ( $(\mathrm{f}=3)$. Candidates stated that each riddle and puzzle has interrelated parts in itself like the rings of a chain, that the completion of the riddle and puzzle is not possible if even one of the pieces is absence, that the subjects of the biology course are linked with each other like the rings of a chain. Accordingly, the opinions of the candidates are: "Biology lesson is like a puzzle because we reach the whole when we compile the pieces" (S120); "Biology is like a puzzle because every learned information is like the complement of the earlier one" (S58); "Biology is like a Jenga game because it needs self-confidence and not everyone can understand it." (S107). 
Table-5. The conceptual categories of metaphors created for biology course.

\begin{tabular}{|c|c|c|c|c|}
\hline Conceptual Categories & $\mathbf{f}$ & $\%$ & Metaphors & Number of metaphor \\
\hline Source of life & 52 & 43.44 & $\begin{array}{l}\text { Life, Life sciences, sun, water, } \\
\text { heart, oxygen, organ, shadow, life } \\
\text { philosophy }\end{array}$ & 9 \\
\hline $\begin{array}{l}\text { A group of topics related to each } \\
\text { other }\end{array}$ & 10 & 8.46 & $\begin{array}{l}\text { Riddle, machine, domino, } \\
\text { matryoshka doll, puzzle, Jenga }\end{array}$ & 6 \\
\hline A branch of science & 7 & 5.98 & Anatomy, science, chemistry & 3 \\
\hline A discipline requiring effort & 5 & 4.27 & Flower, sapling, rose & 3 \\
\hline $\begin{array}{l}\text { A discipline including natural } \\
\text { knowledge }\end{array}$ & 5 & 4.27 & Nature, living things, adaptation & 3 \\
\hline A pleasant discipline & 5 & 4.27 & $\begin{array}{l}\text { Chocolate, food, lahmacun, } \\
\text { Fenerbahçe, driving a car }\end{array}$ & 5 \\
\hline An afflicting discipline & 4 & 3.41 & $\begin{array}{l}\text { Weight, torture, trouble, prayer } \\
\text { bead }\end{array}$ & 4 \\
\hline $\begin{array}{l}\text { A discipline including medical } \\
\text { knowledge }\end{array}$ & 4 & 3.41 & Doctor, first aid kit, drug & 3 \\
\hline $\begin{array}{l}\text { A discipline with limitless } \\
\text { knowledge }\end{array}$ & 4 & 3.41 & $\begin{array}{l}\text { Horizon } \\
\text { line, space, universe, looking to } \\
\text { the earth from space }\end{array}$ & 4 \\
\hline A guiding discipline & 4 & 3.41 & Friend, life coach, guide, book & 4 \\
\hline An ungrateful discipline & 4 & 3.41 & $\begin{array}{l}\text { Cat, drilled plastic bottle, antique } \\
\text { car }\end{array}$ & 3 \\
\hline $\begin{array}{l}\text { A discipline leading to be an } \\
\text { explorer }\end{array}$ & 3 & 2.56 & Research, exploration & 2 \\
\hline A challenging discipline to learn & 3 & 2.56 & Memorizing, verbal lesson & 2 \\
\hline A group of complex topics & 3 & 2.56 & Labyrinth, whirlpool & 2 \\
\hline $\begin{array}{l}\text { A discipline giving an aesthetic } \\
\text { spirit }\end{array}$ & 2 & 2.29 & Art, poetry & 2 \\
\hline A discipline evoking admiration & 2 & 2.29 & Dream, miracle & 2 \\
\hline
\end{tabular}

The most frequent created metaphor in "a branch of science" category was medicine $(f=4)$. The prospective teachers said medical science deals with human physiology and biology course include subjects explaining human anatomy just like medical science, and they created the "medicine" metaphor associated with it. One of them stated, "Biology is like medicine because it introduces our body" (S72). Also, anatomy and chemistry metaphors were created. For example, (S59) stated, "Biology is like chemistry because it analyzes living things to the tiniest building block."

In "a discipline requiring effort" category, they created three metaphors, such as flowers, saplings, and roses. They generally stated they grew and developed as a result of a process requiring labor such as watering and maintaining the plants and the biology lesson requires working, labor and effort, just like plant growth, and its scope could be learned and conveyed into a life better as long as one studies it. One of them said, "Biology lesson is like sapling because it is more clearly understood as necessary effort are exerted, like the transformation of an adequately watered sapling into a tree (S21)."

In "a pleasant discipline" category, prospective teachers expressed they considered the biology course exciting and pleasant, and created metaphors by connecting them with the concepts giving pleasure and excitement. Hence, (S92) said, "Biology lesson is like driving a car because it gives fun as you learn."

In "an afflicting discipline" category, prospective teachers displayed their negative attitudes with metaphors. For instance, one of the candidates stated, "Biology is like weight because not everyone can lift it." (S106), and the other candidates, "Biology is like trouble because suffering from it never ends" (S14). In "an ungrateful discipline" category, they exhibited their negative attitudes because they considered it needs a constant effort, and the knowledge acquired by long efforts was forgotten in a short time if the effort reduced. They created metaphors like "Biology lesson is like a cat because it is ungrateful and quickly forgotten." (S51); "Biology is like an antique car because if you care, it will work; if you do not, it will leave you in the road" (S7). In "a tough discipline to learn" category, they said that although the biology course is in numerical courses, its scope included verbal knowledge and was usually learned by memorizing, and hence the biology course was challenging to learn. One of them stated, "Biology lesson is like memorizing because it includes a lot of verbal knowledge and success is difficult without memorization" (S97). In "a group of complex issues" category, they asserted that the scope was pretty complicated, the subjects were highly related to each other, and that reaching a meaningful whole with the information gained from the course was challenging. One of them expressed, "Biology lesson is like a whirlpool because everything is associated with each other" (S 64).

In "a discipline including medical knowledge" category, the most created metaphor was "doctor" $(\mathrm{f}=2)$. The participants asserted that doctors were included in defining the area, causes, and treatment of various diseases in our body and that the biology course presented information just like a doctor in terms of human anatomy, potential damage to it, and different treatments. One of the candidates said, "Biology is like a doctor because it assists us in predicting the cause of troubles in our bodies." (S67).

In "a discipline including limitless knowledge" category, prospective teachers said that the framework of the course was limitless, just like a horizon line, space, universe, and looking to space. The opinions of some of them are as such: "Biology is like a horizon line because you can never approach and fully comprehend it even if you think you get close." (S40); "Biology is like space because you cannot help exploring it." (S96).

In "a guiding discipline" category, they said that real friends, life coaches, guides, and books direct individuals about how they act, and biology courses generally present information about body structure and life. One of them said, "Biology is like a friend because life cannot be continued without it." (S98). However, others stated, "Biology is like a life coach because it explains everything about our body and health." (S70). 
In "a discipline leading to be explorer" category, the metaphor frequently created was "exploration" $(\mathrm{f}=2)$. They created metaphors by asserting that new information was obtained as they explored and that biology course was open to getting new knowledge in almost every course. For example, one of the candidates said, "Biology is like exploring because new information facilitates learning." (S 34).

Through these metaphors in "a discipline giving aesthetic spirit" category, they declared the organization of subjects of biology courses, and visuals presented during the description of subjects produced aesthetic spirit. One of them said, "Biology is like art because their subjects are in order and please to the eye." (S128); the other, "Biology is like poetry because just as poetry exhibits our feelings, biology shows details about our nature and body structure." (S111). In "a discipline evoking admiration" category, two metaphors (imagination and miracles) were created by two prospective teachers. They stated that the subjects of biology courses were fascinating and evoked admiration with its detailed knowledge. One of them said, "Biology is like a dream because it has many beauties, it fascinates you, and you do not want it to end." (S83).

\section{Discussion and Conclusion}

In the research, prospective teachers' attitudes generally were positive at the level of "agree." In the literature, there are various studies on students' positive attitudes at the primary, middle, and high school levels (Erdemir \& Bakırcı, 2009; Hussaini, Foong, \& Kamar, 2015; Mutlu, 2006; Prokop., Tuncer, \& Chuda, 2007; Trumper, 2006). However, in a few studies, students were found to be prejudiced toward biology courses and dislike them and have a negative attitude (Gül \& Yeşilyurt, 2010). In the study by Ekici and Hevedanlı (2010) investigating the attitudes of high school students, students were found to have a modest attitude. According to the research, positive attitudes can be linked with the students' past experiences, teachers, professors giving biology lessons, and the students themselves. The fact that prospective teachers are interested in biology and faculty members' ability is to link the course to daily life, to make students like the course, and to create awareness about its advantages may create such a result. Factors positively affecting students' attitudes are teacher's desire to make students like the course, connecting the course with daily life, illustrating the application fields of course in professional life, highlighting the role of course in the improvement of critical thinking and reasoning skills, decisive communication with students, the students' interest in the course, self-confidence in learning the course (Arıcl, 2013; Sarıer, 2016). Attitudes, a part of the education process, have a meaningful impact on learning. Decisive attitudes of students cause an improvement in academic success (Uyanı, 2017; Yenilmez \& Ozabacı, 2003). Therefore, it is essential to plan and conduct the teaching and learning process of the course to develop it. The instructors should be informed about factors influencing the attitude toward the course and should arrange the teaching practices accordingly.

In the study, no significant difference was observed in science teachers' attitude scores by gender. In several studies, no difference was found in attitude scores of the learners by gender (Hussaini et al., 2015; Nasr \& Soltani, 2011; Usak et al., 2009). In various studies, the scores were decided to reveal a significant difference on the side of females (Cevik \& Ekici, 2008; Ekici \& Hevedanlı, 2010; Mutlu, 2006; Pehlivan \& Köseoğlu, 2010; Prokop, Prokop, \& Tunnicliffe, 2007; Tosun, 2011; Uyanık, 2017). The reason for obtaining such findings may include many factors like lecturers, students, the content of the course, learning environment. The similarity of teaching strategies, methods, and techniques used by teaching staff conducting biology courses in the faculty where the research is done may cause the prospective male and female teachers to like biology courses at almost equal levels and develop a positive attitude. The content of the course could stimulate interest in both genders, and prospective teachers found the course essential and necessary. As a result of the first sub-problem of research, the fact that the item with the highest level of participation was" I believe what I learned in biology course was helpful for me" confirms this interpretation.

In the study, no significant difference was found between the attitudes of biology teachers by class levels. Similar results existed in Gül and Yeşilyurt (2010) research. One probable reason may be the distribution of biology-related courses in the science teaching undergraduate curriculum according to classes. In science teaching curriculum of Higher Education Institution (2006) the courses "general biology-I" and "general biology laboratoryI" in the third term, "general biology-II" in the fourth term, "general biology laboratory-II" and "conservation of natural life" in the fourth term, "human anatomy and physiology" in the fifth term, "genetic and biotechnology" and "environmental science" and "environmental science" in the sixth term, "evolution" in the seventh term, "food chemistry and biological importance of food" in the eighth term were given. In other words, in the six terms of eight-term education, prospective science teachers receive biology courses. Still, this result gained from the research is different from the results of the researches in which the attitudes of students declined as the class level increased (Baykul, 1990; Pehlivan \& Köseoğlu, 2010; Prokop. et al., 2007). The fact that the sample groups of these researches composed of secondary level students may have caused to different conclusions. The lack of studies analyzing the attitudes by class levels is a significant gap to be filled in the literature. Researching with other population and sample to examine the attitudes of university students or prospective science teachers by class level, or conducting studies to reveal the attitudes of university students from different class levels is recommended to contribute to the literature.

It was concluded that prospective teachers created 57 different metaphors. The most frequently created metaphors are "life" ( $\mathrm{f}=37$ ) and "water " $(\mathrm{f}=6)$. They asserted that biology is a course covering almost all kinds of knowledge and skills associated with life and that the knowledge and skills gained in this course are an essential need, like water. Harman and Cökelez (2017) discovered that metaphors frequently created are "life" and "water". Ulukök et al. (2015) declared that "life" is one of the initial images coming to the minds of the majority of prospective science teachers on the concept of biology. Likewise, in the study by Yapıcı (2015); GürbüzoğluYalmancı and Aydın (2013) the most frequently created metaphor was determined to be the "life."

In the research, 16 conceptual categories were developed by considering the characteristics of metaphors created by prospective teachers. The categories such as biology as a source of life, a group of topics related to each other, a discipline requiring effort, a discipline including natural knowledge, a pleasant discipline, a discipline including medical knowledge, a discipline including limitless knowledge, a guiding discipline, a discipline leading to be an explorer, a discipline giving an aesthetic spirit, and a fascinating discipline include positive metaphors. Some of these 
categories are similar to the research conducted by Ulukök et al. (2015); Yapıcı (2015); Gürbüzoğlu-Yalmancı and Aydin (2013). The reason for the positive metaphors involves that the prospective teachers can like the lesson because they affiliate the subjects with the daily life, have pleasure, get the information they need in daily life, and get an opinion about the source of the information they frequently practice. Besides, the categories of biology as an ungrateful, tough to learn, and complex topics created in the research involve negative metaphors. The categories like a challenging discipline to learn and complex topics are included in the category of "difficult and complex" in Harman and Cökelez (2017). One of the sources of these negative metaphors for biology may be the uninterested experiences of prospective teachers in the past because one of the factors influencing the formation of attitudes is the experience (Tavşancıl, 2014).

Negative attitudes can lead to various levels of negativity in prospective teachers' obtaining knowledge within the scope of a biology course, creating new knowledge and attitudes toward teaching biology subjects in the future years of their career. Therefore, it is recommended that these negative attitudes of prospective teachers be altered into positive through a well-arranged education process. The faculty members must take responsibility. At the beginning of the academic year, teacher educators can determine the prospective teachers' attitudes using metaphors, identify the reasons for negative attitude with the sources of metaphors and conduct studies like new activities, the student-based arrangement of the learning environment with visual activities, research-based studies, usage of the laboratory to eliminate this situation.

\section{References}

Aktaş, M. (2012). Researching the effect of the 5E learning model and cooperative learning metod on academic achivement and attitude in biology lesson. Unpublished Doctoral Thesis, Gazi University Institute of Education Sciences, Ankara, Turkey.

Aricı, O. (2013). A scaling study for the factors affect the attitudes of students towards maths lesson according to the views of teachers. Ege Journal of Education, 14(2), 25-401.

Atasoy, E., \& Ertürk, H. (2008). A field study about environmental knowledge and attidudes of elementary scool students. Erzincan University Journal of Education Faculty, $10(1), 105-122$.

Atik, A. D., Kayabaşı, Y., Yağcı, E., \& Unlü-Erkoç, F. (2015). The secondary school students biology science and course attitude scale: Analysis of reliability and validity. Mehmet Akif Ersoy University Journal of Education Faculty, 1(36), 1-18.

Baykul, Y. (1990). Changes in attitudes towards mathematics and science lessons from the fifth grade of primary school to the final grades of high school and equivalent schools, and success in student placement exam and some factors that are thought to be related. Ankara: OSYM Publications.

Cevik, M., \& Ekici, G. (2008). Examination of vocational high school students' attitudes towards biology lesson according to different variables. Paper presented at the 17. National Educational Sciences Congress, Sakarya, Turkey.

Cömert, G. G. (2014). The effect of project based learning oriented instruction on students' understanding of human circulatory system concepts and attitude toward biology. Unpublished Doctoral Thesis, Orta Doğu Teknik University Institute of Science, Ankara, Turkey.

Doğru, M., Gençosman, T., Ataalkın, A. N., \& Seker, F. (2012). Analysis of master's and doctoral theses studied in science education. Journal of Turkish Science Education, 9(1), 49-64.

Ekici, G., \& Hevedanl, M. (2010). Investigation of high school students' attitudes towards biology course in terms of different variables. Journal of Turkish Science Education, 7(4), 97-109.

Erdemir, N., \& Bakirci, H. (2009). The change and the development of attitudes of science teacher candidates towards branches. Kastamonu Education Journal, 17(1), 161-170.

Forceville, C. (2002). The identification of target and source in pictorial metaphors. Journal of Pragmatics, 34(1), 1-14. Available at: https://doi.org/10.1016/s0378-2166(01)00007-8.

Gül, S., \& Yeşilyurt, S. (2010). Secondary education students' attitudes towards biology and biology lesson (pilot study). Mehmet Akif Ersoy University Journal of Education Faculty, 20, 28-47.

Gürbüzoğlu-Yalmancı, S., \& Aydın, S. (2013). Pre-service teachers' metaphorical perceptions towards biology. Mustafa Kemal University Journal of Social Sciences Institute, $10(21)$, 208-223.

Harman, G., \& Cökelez, A. (2017). Pre-service early childhood education teachers' metaphorical perceptions towards chemistry, physics and biology. Marmara University Atatürk Faculty of Education Journal of Educational Sciences, 46(46), 75-95.

Higher Education Institution. (2006). Education faculty teacher training undergraduate programs. Retrieved from: http://www.yok.gov.tr. [Accessed 05.03.2018].

Hussaini, I., Foong, L. M., \& Kamar, Y. (2015). Attitudes of secondary school students towards biology as a school subject in Birninkebbi Metropolis, Nigeria. International Journal of Research \& Review, 2(10), 596-600.

Kabaca, A. (2013). School teacher candidates attidudes towards constructivist approach, towards biology lessons and achievement in some biology subjects. Unpublished Master Thesis, Balıkesir, University Institute of Science, Balıkesir, Turkey.

Konu, M. (2017). The effect of context and problem based instruction on the students'achievements, attitudes, motivations and problem solving skiils in biology course. Unpublished Doctoral Thesis, Atatürk University, Institute of Educational Sciences, Erzurum,Turkey.

Köseoğlu, P. (2010). The İnfluence of jigsaw technique-based teaching on academic achievement, self-efficacy and attitudes in biolology education. Hacettepe University Faculty of Education Journal, 39(2010), 244-254.

Lodish, H., Berk, A., Kaiser, C. A., Krieger, M., Scott, M. P., Bretscher, A., \& Matsudaira, P. (2011). Molecular cell biology. (Trans: Geçkil, H.,

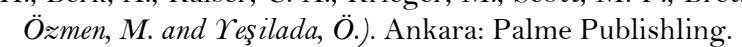

Miles, M. B., \& Huberman, A. M. (1994). Qualitative data analysis: An expanded sourcebook (2nd ed.). USA: Sage Publication.

Morgan, G. (1998). Organization metaphors in management and organizational theories. (Trans: Bulut, G.). Istanbul: Mess Publishing.

Mutlu, M. (2006). The relation between the learning styles of the students in Anatolian high schools, Anatolian teachers' high schools, science high schools and their attitudes towards biology course. International Journal of Environmental and Science Education, 1(2), $148-162$.

Nasr, A., \& Soltani, A. (2011). Attitude toward biology and it's effects on student's achievement. International Journal of Biology, 3(4), 100-104. Available at: https://doi.org/10.5539/ijb.v3n4p100.

Onder, R. (2015). The effect of the interactive whiteboard use in biology lesson on students' achievements and attitudes towards the course and the interactive whiteboard. Unpublished Master Thesis, Dokuz Eylül University Institute of Educational Sciences, İzmir, Turkey.

Osborne, J., Simon, S., \& Collins, S. (2003). Attitudes towards science: A review of the literature and its implications. International Journal of Science Education, 25(9), 1049-1079. Available at: https://doi.org/10.1080/0950069032000032199.

Ozatl, N. S. (2006). Determination of the topics perceived as diffucult by the students in biology lessons and putting forth their cognitive structures about excretion system for consideration by new techniques. Unpublished Doctoral Thesis, Balıkesir University Institute of Science, Balıkesir, Turkey.

Oztürk-Akar, E. (2014). Constraints of curriculum implementation as perceived by Turkish biology teacher. Education and Science, 39(174), $388-401$.

Pehlivan, H., \& Köseoğlu, P. (2010). Attitudes towards biology course and the academic self concept of the students attending at Ankara science high school. Hacettepe University Journal of Education, $38(2010)$, 225-235.

Prokop, P., Prokop, M., \& Tunnicliffe, S. D. (2007). Is biology boring? Student attitudes toward biology. Journal of Biological Education, 42(1), 36-39. Available at: https://doi.org/10.1080/00219266.2007.9656105.

Prokop., P., Tuncer, G., \& Chuda, J. (2007). Slovakian students' attitudes toward biology. Eurasia Journal of Mathematics. Science E Technology Education, 3(4), 287-295. 
Reece, J. B., Urry, L. A., Cain, M. L., Wasserman, S. A., Minorsky, P. V., \& Jackson, R. B. (2013). Campbell Biology. (Trans: Gündüz, E. \& Türkan, $\dot{I}$.). Ankara: Palme Publishing.

Rodrigues, F. F. L., Santos, M. A. D., Teixeira, C. R. d. S., Gonela, J. T., \& Zanetti, M. L. (2012). Relationship between knowledge, attitude, education and duration of disease in individuals with diabetes mellitus. Acta Paul Enferm, 25(2), 284-290.

Saban, A. (2009). Prospective teachers' mental images about the concept of student. The Journal of Turkish Educational Sciences, 7(2), 281-326.

Sarıer, Y. (2016). The factors that affects students' academic achievement in Turkey: A meta-analysis study. Hacettepe Univercity Journal of Education, 31(3), 609-627.

Semenderoğlu, F. (2012). The effect of a constructivist education program designed on high school students' perceptions about the genetic structure of human and genome project, misconceptions and attitudes towards biology lesson. Unpublished Doctoral Thesis, Dokuz Eylul University Institute of Educational Sciences, Izmir, Turkey.

Simşek, H. (2011). Effects of gender inequalities on women's reproductive health: The case of Turkey. Dokuz Eylül University Journal of Medical Faculty, 25(2), 119-126.

Tavşancll, E. (2014). Measurement of attitudes and data analysis with SPSS (5th ed.). Ankara: Nobel Publishing.

Thornbury, S. (1996). Teachers research teacher talk. ELT Journal, 50(4), 279-289. Available at: https://doi.org/10.1093/elt/50.4.279.

Tosun, Z. D. (2011). Developing a biology attitude scale. Unpublished Doctoral Thesis, Gazi University Institute of Educational Sciences, Ankara, Turkey.

Trumper, R. (2006). Factors affecting junior high school students' interest in physics. Journal of Science Education and Technology, 15(1), 4758.

Ulukök, Ş., Bayram, K., \& Selvi, M. (2015). Mental images of science teacher candidates related to the concept of biology (Metaphor analysis example). International Online Journal of Educational Sciences, 7(3), 244-259.

Ummanel, A. (2017). Metaphorical perceptions of preschool, elementary and secondary school children about science and Mathematics. Eurasia Journal of Mathematics, Science and Technology Education, 13(8), 4651-4668. Available at: https://doi.org/10.12973/eurasia.2017.00956a.

Unal, G. (2005). Domestic violence. Journal of Social Policy Studies, 8(8), 77-85.

Unal., S., \& Dımışkı, E. (1999). The development of environmental education and secondary education under the auspices of the UNESCOUNEP environmental education in Turkey. Hacettepe Univercity Journal of Education, 17(17), 142-154.

Usak, M., Prokop, P., Ozden, M., Ozel, M., Bilen, K., \& Erdogan, M. (2009). Turkish university students' attitudes toward biology: The effects of gender and enrolment in biology classes. Journal of Baltic Science Education, 8(2), 88-96.

Uyanı, G. (2017). The relationship between attitudes towards science course and academic achievements of primary school students. TÜBAV Science, $10(1), 86-93$.

Yapıc1, U. İ. (2015). High school students' metaphorical perceptions towards biology. Electronic Journal of Social Sciences, 14(55), 139-147.

Yenilmez, K., \& Ozabacı, N. S. (2003). A study on the relationship between mathematics anxiety levels and attitudes of boarding teacher school students. Pamukkale Univercity Journal of Education, 14(14), 132-146.

Zheng, H.-B., \& Song, W.-J. (2010). Metaphor analysis in the educational discourse: A critical review. Online Submission, 8(9), 42-49. 